\title{
Industrial Policy Response to the Covid 19 Crisis in Ireland - A Filière Approach
}

\author{
Bernadette Andreosso-O 'Callaghan*
}

\begin{abstract}
The economic shock represented by the Covid19 crisis has been showing the limits of industrial policy choices such as that of the chosen globalisation model, a model characterised in particular by the relocation of "key" manufacturing activities away from EU countries and towards low-cost emerging countries. In relation to the Covid19 crisis, relocation emanates from industrial policy choices that have weakened the health filière (encompassing the chemicals \& pharmaceutical manufacturing industries and the health service industry). The specific case of Ireland shows a strong manufacturing specialisation in the relatively resilient pharmaceutical industry, a strength undermined by a relatively inefficient health service industry. National policy responses have taken the form of a large number of schemes estimated to amount to some $€ 5 \mathrm{bn}$. Questions arise in terms of the ability of the EU, and of Ireland therein, to secure its health sovereignty in the future, and in terms of the implications of growing indebtedness, particularly in the euro-area
\end{abstract}

Keywords: European Economy; Industrial Strategy; Modern Companies; Global Markets; Territory; Governance

\section{The COVID 19 Crisis in the EU}

The 2020 health and economic crisis that has unfolded gradually in the EU - due to the spread of COVID 19 originating in Wuhan Province, China - has shown and revealed further the economic fragility resulting from some industrial policy choices made by the European Commission and by single EU Governments over the past decades. First, the belief that sustainable economic growth was paralleled with deindustrialisation: a growth that relied increasingly on services and in particular on ICT-based and financial services. Second, the belief that relocation to China and to other low-cost locations of what has been defined as "key" industries or products (Andreosso-O'Callaghan \& Jacobson, 2005) was a satisfactory model of globalisation. Third, a gradual disengagement of the state in EU countries from the public sector and in particular from the health sector. These policy choices have resulted in the weakening of the health filière in all EU countries, albeit to various degrees. In particular, the sudden shortage of "key" medical supplies and equipment in EU countries at the height of the COVID19 crisis, resulting from the loss by EU firms of their control in the production of these manufacturing products, has caused a high (and partly avoidable) death toll, and has led to the EU economy shutting down

*Full Professor of Economics, University of Limerick (bernadette.andreosso@ul.ie)

Edited by: Niccolò Cusano University

ISSN: 1593-0319

Andreosso-O'Callaghan B. (2020). Industrial Policy Response to the Covid 19 Crisis in Ireland - A Filière Approach Symphonya. Emerging Issues in Management (symphonya.unicusano.it), (2), 80-88. 
for several weeks and months, resulting in the sharpest economic contraction since World War 2 (European Commission, 2020).

By using the case of the Irish economy as a case study, this contribution is aimed at analysing the impact of this health crisis on Ireland's manufacturing sector, its performance and its outlook in the background of the crisis. Specific attention will be devoted to the notion of health filière including the chemicals and pharmaceutical industry as well as the health service sector, despite the relatively small size of the Irish economy. This is motivated by the fact that, in the group of EU28 countries, Ireland stands out as a country having a strong industrial specialisation in the pharmaceutical industry (Nace code 21), which is the largest industry in terms of sales (net selling value or NSV); this industry ranks well before the food, chemical products and computers industries. All four industries represented in 2018 more than 80 per cent of all Irish manufacturing NSV, with pharmaceutical alone representing about 40 per cent of the total manufacturing NSV (or half of that of the "big four"). This is sharp contrast with the situation at the level of the EU as a whole, where the pharmaceutical industry represented only 3.5 per cent of the NSV in the same year (CSO, 2020).

\section{Industrial Sectors' Contribution to Irish Growth (pre-Covid and post-Covid Adjustments)}

By using the NNP measure (net national product), in order to correct for the relative importance of foreign firms repatriating their profits abroad (mostly US-owned), the different broad industrial sectors' contribution to pre-Covid growth for the period 2013 to 2018 shows that the public administration, health and education sector accounted for 20 per cent of NNP. The distribution sector also accounted for nearly 20 per cent, whereas the manufacturing's share in NNP was smaller at 13 per cent (Fitzgerald, 2020). The overall share of the financial sector in Irish NNP, at almost 10 per cent, is high by international standards. When broken down by ownership, the analysis shows that foreign multinational enterprises (MNEs) operating in Ireland represent about 20 per cent of NNP and that this share has been rather stable since the economic recovery from the global financial crisis began in 2013. Domestic firms in the manufacturing and in the information technology communications sector (ITC), have a smaller share of gross value added (GVA) when compared to foreign firms, but represent nearly as large a contribution to NNP (Fitzgerald, 2020).

In the group of EU countries, Ireland stands out as a country having a strong industrial specialisation in the pharmaceutical industry (Nace code 21). The Pharmaceutical industry in Ireland is indeed the largest manufacturing industry in terms of sales (net selling value or NSV), and it ranks well before the food, chemical products and computers industries. All four industries represented in 2018 more than 80 per cent of all Irish manufacturing NSV, with pharmaceutical alone representing about 40 per cent of the total manufacturing NSV (or half of that of the "big four"). This is sharp contrast with the situation at the level of the EU as a whole, where the pharmaceutical industry represented only 3.5 per cent of the NSV in the same year (CSO, 2020). Well established pharmaceutical companies' names such as Gilead Sciences have a manufacturing presence in Ireland. The expansion of the Cork (Carrigtwohill) plant in 2018 with an injection of a $€ 9.5 \mathrm{mn}$ investment in order to 
extend quality control operations and to increase the production of drugs for the European, Asian and Middle-Eastern markets allows Gilead's Irish facility to produce a quarter of all products delivered via tablets with a workforce of close to 400 people.

At a macroeconomic level, some estimates (Department of Finance, 2020a) suggest that about 32 per cent of Irish GNI (Gross National Income) and 37 per cent of gross domestic (Irish) value added is generated by industries directly affected by the containment measures. In Ireland and elsewhere in the EU, the new 2020 health crisis has had nevertheless a differentiated impact on industries and sectors, with the tradable goods, transport and hospitality sectors (including entertainment/arts) having been the most affected sectors of all. Other industries or sectors such as packaging and chemicals \& pharmaceutical have been the least affected areas whereas a mild negative impact was felt in the case of the agriculture/forestry/fishing sector as well as for financial services. With the manufacturing sector as a whole comprising a number of so-called "essential" productive activities that remained open during the lock-down period in Ireland, the manufacturing sector as a whole has tended to be less impacted upon when compared to the broad services sector. According to Daly and Lawless (2020), the manufacturing sector should show a degree of resilience in 2020; manufacturing output is actually expected to grow given the dominant share in this sector of the pharmaceutical industry (and also of chemicals) that is expected to be relatively unaffected by the health crisis. All in all, the Central Bank of Ireland have forecast an Irish GDP growth rate of - 9 per cent for the year 2020 (-2.5 per cent according to the Irish Department of Finance September), which suggests a smaller contraction than that expected in many other EU countries. However, the other main shock - this time asymmetric - for the Irish economy is represented by the Brexit challenge, given the still tight links existing between the Irish and British economies. When crossing the impact of both shocks, COVID19 and Brexit, Daly and Lawless (2020) find that there is limited sectoral overlap between the two shocks, with, for example the hospitality and construction sectors having been the most severely affected sectors by the health crisis, but being at the same time rather sheltered from the Brexit shock. A reverse scenario applies to the case of the financial and insurance sector.

\section{Main Issues Arising in the Irish Health Sector of Ireland in the Background of the Covid19 "Pandemic"}

With regard to the Covid19 epidemic, Ireland displays mid-range lethality rates compared with other EU and western countries. As of the 8th of October 2020, the lethality rate (number of deaths attributed to Covid19 as a proportion of confirmed Covid19 cases) was 4.59 in Ireland against 10.8 in Italy, 7.83 in the UK, 7.53 in Belgium and 2.82 in the USA (Statista figures). This mid-range performance can be attributed to a combination of factors: the small size of the economy (not all pharmaceutical equipment and drugs can be produced in a small economy) and the disruption of global value chains encompassing China; the lack of an appropriate treatment for Covid19 patients during the first months of the pandemic; the historical underfunding of Ireland's public sector and in particular of its health sector. This latter phenomenon has tended to be aggravated by the restrictive fiscal measures 
introduced after the 2008 crisis and by an endemic poor management of resources in the health sector. As a result, Ireland went into one of the longest periods of economic lockdown of all EU economies with a damaging impact on economic activity. Industrial production alone decreased by 7.6 per cent in April 2020 (CSO, 2020) and the OECD June 2020 estimates put the growth rate for 2020 at $-63 / 4$, a figure that was revised in September to $-2.5 \%$ by the $\mathrm{CSO}$, although this was just before the enactment of yet more restrictive lockdown measures since the beginning of October 2020.

The performance of the Irish Health sector (as part of the wider health filière) needs to be analyzed in light of two main issues: the question of expenditure or/and investment in the health service sector, and the issue of the return on this investment. According to a recent report by the ESRI (2020), and when adjusting for relative prices, so as to compare the volume of healthcare consumed, Ireland's total healthcare expenditure per capita ranked ninth in 2017 in the OECD group, and the country was ranked first in terms of healthcare expenditure as a percentage of national income. Do these apparently commendable rankings translate into the provision of state-of-the-art health services? When looking at the data on how the money disbursed is actually invested, and by using some basic performance indicators, Ireland performs rather poorly. For example, data provided by Statista show that the number of hospital beds in Ireland declined by 58 per cent (from 21,789 to 12,813 ) between 2008 and 2009, although this number increased again to 14,217 in 2017 in line with Ireland's post global financial crisis economic recovery. In the specific area of intensive care unit (ICU) beds, Ireland had 240 such beds in 2014. This figure declined to 225 before the Covid19 outbreak, and temporary beds were eventually created allowing to reach the figure of 354 ICU beds in April 2020, with a total capacity of 411 beds for patients requiring intensive care facility at the height of the pandemic. The number of ICU beds declined again to 280 at the end of September 2020.

Undoubtedly, this decline is also visible in most EU countries, with the exception of some Eastern countries such as Poland. For example, figures released by the German DIVI (2020) show that the decline has also affected a number of highincome EU countries such as Germany when looking at either total hospital beds of intensive-care unit (ICU) beds. Despite the decline, Germany managed to keep more than 38 ICU and critical care beds per 100,000 people in 2017; this compares with 6.5 such beds for Ireland shortly after the 2008 financial crisis (Rhodes et al, 2012). Another issue is the occupancy ratio in hospitals which stands at 62 per cent in Germany compared with a ratio close to 95 per cent for Ireland, the highest ratio in the OECD league.

Understandably, medical research and efficiency in the case of various treatments might explain some of the decline in intensive care unit (ICU) beds or/and acute care hospital beds in Western countries since the 1960s. However, in the case of Ireland, the HSE (Health Service Executive) had stated before the Covid19 outbreak that the country needed 579 such beds (ICU and acute care). Again, at the end of September 2020, the HSE unveiled its new Winter 2020 Plan, described as "unprecedented" government funding with an envelope of $€ 600$ million. The plan includes 17 additional ICU beds, as well as another 500 new acute care beds deployed across all hospitals. Owing to the simple rules of factors of production optimization, and given 
that the staff to patient ratio in such units can be as high as 1:6, the creation of such facilities is constrained by the time lag involved in the training of staff.

A pertinent dual question now is why Ireland shows such a dismal performance and why does there seem to be a chronic underfunding in spite of the high spending in the health service sector? The decline in hospital beds and public sector funding across EU countries is in line with the Maastricht principle of avoiding excessive budgetary deficits. The gradual withdrawal of the state from the public sector can be compensated for by the entry of private investors, promoted through public private partnership schemes. Rulings from the European Court of Justice, in line with the European Commission policies, have implied that services delivered by national health care systems can gradually be considered as an economic activity and these have therefore to comply with the rules of the Single European Market in terms of free movement of goods, persons, capital and services. Consequently, rules in terms of public procurement - in outsourcing key medical equipment for example - and state aids (state funding) apply also in principle to healthcare services. Hermann (2009) refers to the concept of "marketization" of health care provision in the EU. He argues that although the official objective is to improve efficiency, these reforms tend to "promote inequality among patients and healthcare workers and erode the public nature of healthcare provision." The current state of the Irish health care system can only be partially explained by these reforms. Another important element is the increase in managerial activity in the sector, some of it explained by the daily compliance of the health care medical acts with EU regulations. Recent Government of Ireland (2019) figures show that the ratio of non-health care staff tends to be high for Ireland (at 43 per cent without childcare and at 31.2 per cent when childcare is added to the health care staff). This implies that there is a certain degree of inefficiency in the way the funding is divided between managerial/support staff and health care staff.

As a summary, inefficiencies in the Irish health sector, in spite (or because?) of EUbased macroeconomic and health sector reforms has led to one of the longest lockdowns in EU countries, with an unprecedented impact on some industrial sectors. These confinement measures have been seen as the only way to offset the inefficiency of the Irish health service sector. This mirrors the failure of EU policy at several levels. In order to keep some businesses afloat, a number of measures have been put in place at the national level, an issue to which we now turn.

\section{Industrial Policy Response to the Health Crisis and Firms' Strategies}

The question arising here is that of industrial and economic resilience arising from a crisis, and in particular from a health crisis of the Covid19 magnitude. This question is also about the pertinence of targeting "key" sectors, industries or products as core sectors in a satisfactory industrial policy model in line with modern globalisation (Andreosso-O'Callaghan and Jacobson, 2005). As seen above, Ireland is relatively specialised in the pharmaceutical sector, as well in financial services, two sectors that have been relatively sheltered from the crisis. This section will summarise the Covid19 related prevention and recovery measures taken in different industries and sectors so as to sustain businesses. These measures can be divided into short-term and longer-term measures. 
The first group of measures encompass the income support measures such as the COVID-19 Income Support Schemes to help workers and businesses affected by the crisis. In this category were devised an Employment Wage Subsidy Scheme, a Covid19 Pandemic Unemployment Payment (to all employees and the self-employed who lost their jobs) as well as a Short-time Work Support (in case of reduced hours or days worked. A second group of measures relate to a myriad of schemes based on loans, grants and vouchers to firms. These are for example the COVID-19 Credit Guarantee Scheme, with loans ranging from $€ 10,000$ to $€ 1$ million for up to five and a half years; financing is offered through term loans, working capital loans and overdrafts. The COVID-19 Business Loans - up to a financial outlay of $€ 25,000$ are available through Microfinance Ireland with zero repayments and zero interest for the first 6 months. The COVID-19 Working Capital Scheme has an envelope of $€ 450 \mathrm{~m}$. The Sustaining Enterprise Fund of up to $€ 180$ million is aimed at firms operating in the manufacturing and internationally traded services sectors, with 10 or more employees. SMEs are more specifically covered by the Sustaining Enterprise Fund for Small Enterprise which provides a short term working capital injection of up to $€ 50,000$ to eligible smaller companies to support business continuity and strengthen their ability to return to growth. Organizations such as Enterprise Ireland, the IDA (Industrial Development Authority), Local Enterprise Offices and and Údarás na Gaeltachta, for the western counties of the country, are key actors in the management of these schemes that are broadly geared towards the improvement of competitiveness. For example, the Local Enterprise Offices (at sub-national level) are active in the Restart Grant Plus, the Enterprise Support Grant, the Trading Online Voucher and the Micro-Enterprise Assistance Fund. Another organization, Inter Trade Ireland, is active in the area of cross-border companies with its Emergency Business Solutions offering professional advice, to the value of $€ 2,250$ and with the E-Merge programme which provides consultancy support funding to help crossborder businesses develop online sales and e-Commerce solutions. Businesses are also favoured through a voluntary Code of Conduct for commercial rents; with some exceptions, all businesses have been granted a waiver of commercial rates for the six months to end-September 2020.

Fiscal measures include a scheme administered by Revenue which allows for the reduction in the standard rate of VAT (from 23\% to 21\%) and which is effective from 1 September 2020. The Covid Products Scheme, administered through the IDA, is aimed at facilitating the R\&D of COVID-related products. On the training front, the Apprenticeship Incentivisation Scheme, is delivered by SOLAS, with employers being eligible for a $€ 3,000$ payment for each new apprentice. Other training schemes include Enterprise Ireland's eiLearn online learning resource, and the Regional Skills Fora networks.

Finally, specific schemes have been designed for specific industries. For example, Bord Bia's Navigating Change Covid19 Response Programme offers support to the food, drink and horticulture businesses affected by Covid19. Farm businesses can derive support from Teagasc. In the tourism sector, a $€ 26 \mathrm{~m}$ COVID19 Adaptation Fund was devised to support tourism and hospitality businesses who have incurred related adaptation costs. Arts and Entertainment can benefit from a number of schemes such as for example the Music Stimulus Package. Restaurants were allowed to reopen temporarily as takeaways without being required to obtain change of use planning permission. 
The issue of health sovereignty has eventually surfaced in public discourse, and some response has been proffered by the Irish Government in line with an industrial strategy that tries to identify the 'key' areas in terms of economic sustainability. In that regard, and thanks to some preliminary work that had been done in the preparation to Brexit, the Medicines Criticality Assessment Group and the Medical Devices Criticality Assessment Group were asked to proffer guidelines and advice on potential medicines, on barriers to supply and on medical device shortages related to the Covid-19 outbreak. A priority has been to enhance the availability of personal protective equipment (PPE), medicines and medical devices used in diagnosis of Covid-19, treatment of Covid-19, supportive treatments, and treatments of secondary infections. There is also a myriad of procedures and guidance relating to the manufacture and distribution of medical devices, PPE (Personal Protective Equipment) and barrier masks.

The response at EU level is deemed to have a longer-term impact than most of the measures and schemes referred to above. As part of the EU Recovery Fund (worth $€$ $750 \mathrm{bn}$ ), which could become a permanent deficit facility for stabilisation in case of a crisis, Ireland would potentially get $€ 1.9$ billion in grants, which would be issued to finance specific stimulus and reform projects, to be repaid at a later stage, as well as another $€ 1$ billion in loans made available; this would amount to an overall recovery package of roughly $€ 3$ billion for Ireland. Note that the EU recovery plan will be linked to the EU's multi-annual financial framework (2021 and 2027). According to some estimates, Ireland would be a large net contributor to the EU Recovery fund. The contribution is estimated at $€ 18$.7billion over 30 years or so whereas Ireland will only be entitled to about $€ 2$ billion from the non-repayable grants part of the Fund and it could also borrow $€ 1$ billion from the loan part, which makes a net contribution of $€ 3,400$ for each Irish resident (Barnes, 2020). The downside for Ireland is clearly that the country is a net contributor to the EU budget, that it could become a net contributor to this Recovery Fund, while corporate tax consolidation will remain on the agenda of EU finance ministers, adding to uncertainty in the country in the long-term.

\section{Concluding Remarks}

The new health crisis seems to show the limits of the globalisation model pursued by EU firms under the auspices of the EU Commission's Global Strategy, which is based on the key concept of "cost-competitiveness" and which questions the suitability of global value chains in critical sector such as the pharmaceutical and medical equipment sector. Whereas the 2008 crisis had already revealed the fragility of de-industrialisation in toto in the EU, this new health/economic crisis puts to the fore the crucial importance of keeping "key" industrial activities under the control of both EU firms and EU countries. Whether a pan EU analysis in terms of policies is relevant at this stage is a question that can be discussed and analysed. Instead of solidarity being shown to Italy as the first EU country being severely hit by this crisis, the first responses from EU partner countries were surprisingly most counterproductive. France and Germany banned their exports of protective medical gear in early March 2020 (to Italy in particular), and at the end of March 2020, some EU leaders (from Germany, Austria, Holland and Finland) were still reluctant to conceive of an EU cooperative financial plan to kick-start an economic recovery 
process. Eventually, the European Central Bank was able to establish the new PEPP (Pandemic Emergency Purchase Programme) in March 2020 covering some $€$ $1350 \mathrm{bn}$ of both government and corporate bonds from the euro-area. This came in addition to the purchase of $€ 120 \mathrm{bn}$ of government bonds through the Asset Purchase Programme (APP) of the ECB.

As a small open economy, Ireland has had to respond to many crises by adjusting its industrial structure to the various globalisation challenges and by trying to make its economy resilient to further major economic shocks. The country is now well embedded in various global value chains, mostly through the operation of US MNEs. Policy choices made in the past have allowed the pharmaceutical industry to emerge and to rank as the largest manufacturing industry in terms of sales well before other 'key' industries such as food \& drinks, and well ahead of the chemical products and of the computers industries. However, given the small size of its economy (less than 5 million people), the Irish industrial structure is highly specialised in some areas of services (Hedge Funds in the case of the Financial services sector) and manufacturing (pharmaceuticals). Given the preponderance of large foreign MNEs in the pharmaceutical sector in Ireland (such as Boston Scientific, GlaxoSmithKline, Gilead Sciences) in terms of both output and sales, the ability of this small open economy to respond timely and adequately to a health crisis depends in fine on the aptitude of Irish indigenous pharmaceutical companies to engage in flexible specialisation. Since this aptitude is constrained, an important dimension becomes the EU dimension. The recent Covid19 episode seems to suggest that, yet again, EU solidarity is relatively hesitant in the early phase of a crisis. As in the case of the 2008 financial crisis, a great deal of the EU response was delayed (until late July 2020) and a number of schemes were put in place in the meantime by the Irish Government to support the different economic actors and in particular the firms. Aided greatly by the bond purchase programme of the ECB, financial and fiscal support to households, workers and employers, was made possible through a large variety of schemes, which are estimated to amount to some $€ 5 \mathrm{bn}$. About one third of all employees in Ireland were receiving Covid-payment at the highest point in the crisis.

A pertinent question at this juncture is in terms of Ireland's ability to secure its health sovereignty in the future. As we have seen, the country is strong in the area of pharmaceutical products, chemicals, as well as medical equipment, but this strong manufacturing performance needs to be qualified further. The largest share of these companies' output is detained by foreign-owned firms; and, owing to its size, the country is specialized in a number of narrow product niches in these industries. The other main part of the health filière - the health service sector - seems to suffer from a chronic state of underperformance. EU-based reforms fostering the entry of private management tools have accelerated the declining trend in available hospital beds, and the relatively high spending in the health service sector seems to follow the trend of increasing managerial activities. Because of the chronic inefficiency characterizing the Irish health service sector, the lockdown measures have been amongst the longest and the most drastic of all EU countries. Finally, some macroeconomic indicators give some reason for concern. By June 30th 2020, the issuance of Irish Government bonds was already 4.3 times that for the entire year of 2019 (DoF, 2020). Growing indebtedness in Ireland and elsewhere in the euro-area could result in the unfolding of yet another (financial) crisis in the EU. 


\section{Bibliography}

Andreosso-O'Callaghan, B. \& Jacobson, D. (2005). Industrial Economics and Organization - A European Perspective, (2nd Edition). New York and London: Mac Graw-Hill.

Barnes, J. (2020). Ireland to be $€ 16$ Billion Loser from EU Coronavirus Bailout - A Staggering $€$ 3,400 per Person. Express, 3rd August, Brussels.

Brondoni S. M., \& Zaninotto E. (2018). Overture de 'The 4th Industrial Revolution. Business Model Innovation \& Global Competition'. Symphonya. Emerging Issues in Management (symphonya.unimib.it), (2), 1-7.

http://dx.doi.org/10.4468/2018.2.01ouverture

Brondoni, S. M. (2014). Global Capitalism and Sustainable Growth. From Global Products to Network Globalisation. Symphonya. Emerging Issues in Management (symphonya.unimib.it), (1), 10-31. http://dx.doi.org/10.4468/2014.1.02brondoni

Cantoni, F., Graziano, P., Maiocchi, F., \& Rizzi, P. (2019). A Territorial and Organizational Approach to Resilience, in Symphonya. Emerging Issues in Management (symphonya.unicusano.it), (2), 109118.

http://dx.doi.org/10.4468/2019.2.10cantoni.graziano.maiocchi.rizzi

CSO (2020). Industrial Production by Sector (accessed on $30^{\text {th }}$ March at: https://www.cso.ie/en/releasesandpublications/er/iips/irishindustrialproductionbysector2018/)

Central Statistics Office. (2020.). Irish Industrial Production by Sector 2019. Dublin: Central Statistics Office.

Daly, L., \& Lawless, M. (2020). Examination of the Sectoral Overlap of COVID19 and Brexit Shocks, Economic and Social Research Institute, Working Paper No. 677. September. Dublin.

Department of Finance (2020a). Stability Programme Update 2020. DoF, Dublin.

DoF (2020). Fiscal Monitor - Incorporating the Exchequer Statement, Department of Finance, Dublin.

DIVI (2020). DIVI Intensivregister Tagesreport, Deutsche Interdisziplinäre Vereinigung für Intensivund Notfallmedizin e.V. 2020-05-19, Berlin.

ESRI (2020). How does Irish Healthcare Expenditure Compare Internationally? by Wren, M-A. \& Fitzpatrick, A. Economic and Social Research Institute, Research Series N. 114, Dublin, $6^{\text {th }}$ October.

European Commission (2020). European Economic Forecast, Summer 2020 (Interim), Institutional Paper 132, July, Brussels.

Government of Ireland (2019). Health Care in Ireland - Key Trends 2018. Dublin.

Fitzgerald, J. (2020). Understanding Recent Trends in the Irish Economy" (Economic and Social Research Institute, Dublin; ESRI Special Article, June).

Hermann, C. (2010). The Marketisation of Health Care In Europe, Socialist Register, available at: https://www.academia.edu/812430/The_marketisation_of_health_care_in_Europe

OJEU (2011). Directive 2011/24/EU of the European Parliament and of the Council of 9 March 2011 on the Application of Patients' Rights in Cross-Border Health Care. L. 88/45, of the 4th April 2011.

Rhodes, A., Ferdinande, P., Flaatten, H., Guidet, B., Metnitz, P. G., \& Moreno, R. P. (2012). The Variability of Critical Care Bed Numbers in Europe. Intensive Care Medicine. 38 (10): 1647-1653. http://dx.doi.org/10.1007/s00134-012-2627-8 